\title{
LATE NEOGENE ELASMOBRANCH FAUNA FROM THE COQUIMBO FORMATION, CHILE
}

\author{
FELIPE STAIG \\ Departamento de Biología Marina, Facultad de Ciencias del Mar, Universidad Católica del Norte, Coquimbo, Chile. \\ fstaig@gmail.com
}

\section{SEBASTIÁN HERNÁNDEZ}

Sala de Colecciones Biológicas, Facultad de Ciencias del Mar, Universidad Católica del Norte. Larrondo 1281, Coquimbo, Chile. Veritas University, Center for International Programs, Costa Rica.shernandez@veritas.cr

\section{PATRICIO LÓPEZ}

Departamento de Antropología, Facultad de Ciencias Sociales, Universidad de Chile. Centre for Maritime Archaeology Research of the Southeastern Pacific, Santiago, Chile.patriciolopezmend@gmail.com

\section{JAIME A.VILLAFAÑA}

Programa de Magister en Ciencias del Mar and Laboratorio de Paleobiología, Centro de Estudios Avanzados en Zonas Áridas, Coquimbo, Chile.jaime.villafana@ceaza.cl

\section{CRISTIAN VARAS}

Subsecretaria de Pesca, Avenida Ossandón, 890, Coquimbo, Chile.

cvaras@subpesca.cl

\section{LUIS PATRICIO SOTO}

Florida Museum of Natural History, University of Florida, Gainesville, Florida, USA.

luispatricio.soto@gmail.com

\section{JORGE D. CARRILLO-BRICEÑO}

Paleontological Institute and Museum, University of Zürich, Karl-Schmid-Strasse 4, Zürich, 8006, Switzerland. jorgedcb100@gmail.com

\begin{abstract}
Neogene marine sediments from Chilean geological formations contain a diverse marine fossil fauna. In Chile, the "Norte Chico" $\left(27^{\circ} \mathrm{S}\right.$ to $\left.32^{\circ} \mathrm{S}\right)$ is composed of two important sedimentary marine deposits, the Bahía Inglesa and Coquimbo formations. Diverse vertebrate taxa including fish, birds, mammals and abundant chondrichthyans have been described from Bahía Inglesa Formation. However, the vertebrate fauna from Coquimbo Formation has been poorly documented. Based upon field trips and the analysis of collections from the Coquimbo Formation, the elasmobranch fossil fauna is composed of at least nine taxa, two of which are extinct (Carcharocles megalodon and Carcharodon plicatilis). The rest of the taxa are related with living elasmobranch species that are inhabitants of the Eastern Pacific Ocean and Tropical America coast.
\end{abstract}

Key words: Neogene, shark, elasmobranch, chondrichthyans, Coquimbo Formation, Pacific.

RESUMO - Sedimentos marinhos de formações geológicas chilenas do Neógeno contêm uma diversa fauna fóssil marinha. No Chile, o "Norte Chico" $\left(27^{\circ} \mathrm{S}\right.$ to $\left.32^{\circ} \mathrm{S}\right)$ é composto de dois importantes depósitos sedimentólógicos marinhos, as formações Bahía Inglesa e Coquimbo. Uma diversidade de táxons de vertebrados, que inclui peixes, aves, mamíferos além de abundantes chondrichthies, têm sido descritos para a Formação Bahia Bahía Inglesa. Entretanto, a fauna de vertebrados da Formação Coquimbo está pobremente documentada. Com base em trabalhos de campo, bem como na análise de coleções da Formação Coquimbo, observa-se uma fauna de elasmobrâquios composta de pelo menos nove táxons, dois dos quais estão extintos (Carcharocles megalodon e Carcharodon plicatilis). Os demais táxons estão relacionados com as espécies de elasmobrânquios recentes que habitam as costas leste do Oceano Pacífico Leste e da América Tropical.

Key words: Neógeno, tubarão, elasmobrânquio, condrictios, Formação Coquimbo, Pacífico. 


\section{INTRODUCTION}

Evidence of fossil elasmobranchs has been collected from Neogene marine sediments distributed all over the world (Cappetta, 2012). As an example, fossil elasmobranch teeth have been collected and studied from four main Chilean geological formations: Bahía Inglesa $\left(27^{\circ} \mathrm{S}\right)$, Coquimbo (between $29^{\circ} \mathrm{S}$ to $\left.30^{\circ} \mathrm{S}\right)$, Horcón $\left(32^{\circ} \mathrm{S}\right)$ and Navidad $\left(33^{\circ} \mathrm{S}\right)$ (Philippi, 1887; Gigoux, 1944; Long, 1993; Arratia \& Cione, 1996; Suárez \& Encinas, 2002; Suárez \& Marquardt, 2003; Suárez et al., 2004; Carrillo-Briceño et al., 2013). These marine fossil deposits have been commonly found in the northern coast of Chile, and characterized by a high proportion of fossil elasmobranch teeth (e.g. Suárez \& Marquardt, 2003). This particular geographic area is called the "Norte Chico", and is composed of two geological formations: Bahía Inglesa and Coquimbo. The Bahía Inglesa Formation was deposited under marine conditions, and has been well studied geologically (Rojo, 1985; Marquardt, 1999). Different taxa of fish, birds and mammals have been referred from Bahía Inglesa (Long, 1993; Arratia \& Cione, 1996; Walsh \& Hume, 2001; Walsh \& Naish, 2002; Suárez et al., 2004; Acosta et al., 2006; Chávez, 2008), and at least 23 taxa of chondrichthyan species have been described as well (Long, 1993; Arratia \& Cione, 1996; Suárez \& Marquardt, 2003; Suárez et al., 2004). Unfortunately, craftsmen and private collectors recurrently visit the marine sediments in Bahía Inglesa to remove and sometimes sell the fossils.

In comparison with the knowledge of the marine vertebrate fauna from Bahía Inglesa, little is known about the vertebrate marine fossil fauna from the Coquimbo Formation (Philippi, 1887; Long, 1993). The area of Coquimbo has experienced urban and industrial expansion during the last two decades. Consequently, most of the marine fossil deposits have been disturbed, and many of them are now destroyed or buried. In this context, the aim of this study was to characterize the elasmobranch fossil marine deposits from the Coquimbo Formation by describing fossil teeth found under the surface ground layer before the complete destruction of the locality.

\section{MATERIAL AND METHODS}

The material examined consists of isolated elasmobranch fossil teeth that have been collected in different locations from the Coquimbo Formation: Caleta Chañaral, Punta de Choros, Caleta Hornos, La Cantera Baja, La Herradura, Quebrada Las Rosas and El Rincon (Figure 1). The localities La Cantera Baja, La Herradura and Quebrada Las Rosas were already impacted by urbanization. The sampling design consisted of alternating between surface surveys and bulk samples with excavations of up to $1 \mathrm{~m}$ depth. Fossil shark teeth are commonly found in the surface layer in the Coquimbo Formation.

This material is deposited at the Museo Arqueológico de La Serena (MALS), La Serena, Chile. The classifications follow Compagno $(1973,1977)$ and the terminology is based on Cappetta (2012). Measurements taken include height and width, and these refer to the entire tooth including

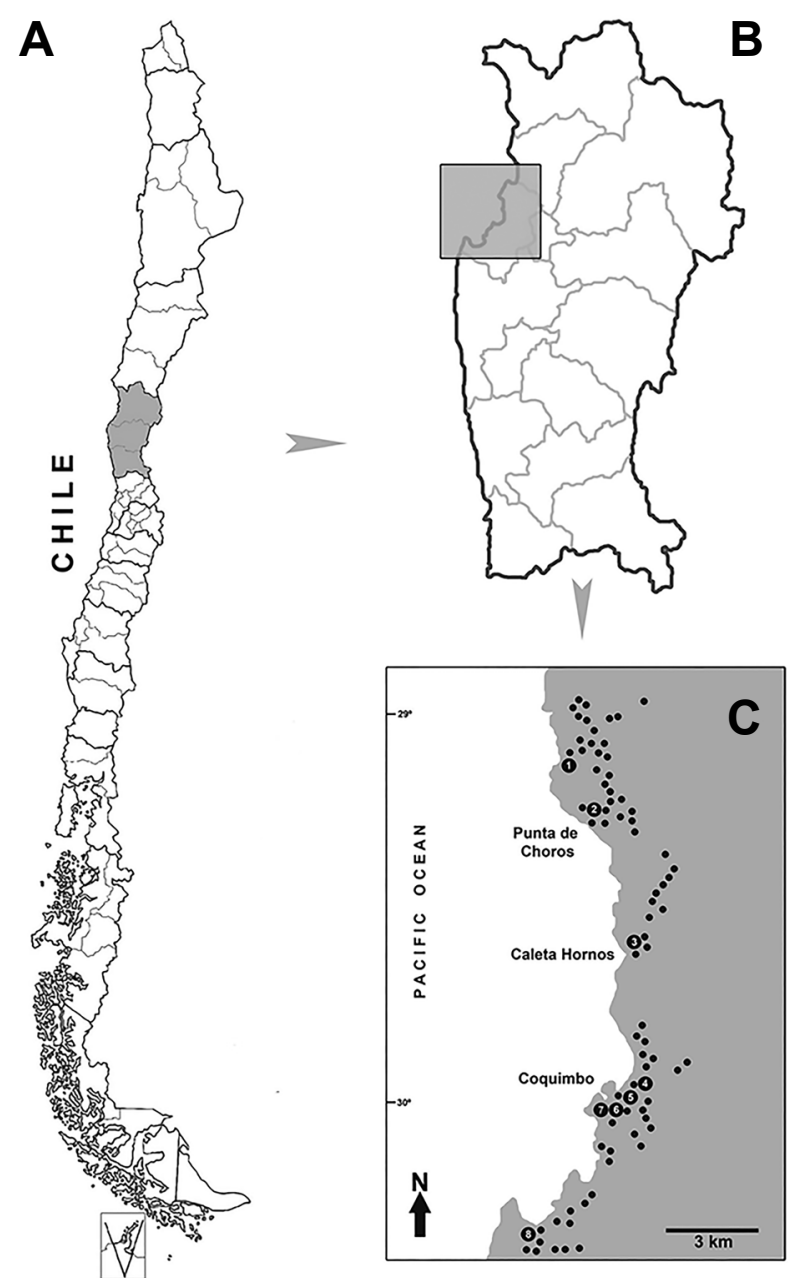

Figure 1. A, map showing the regional representation of Chile. The Coquimbo region is shown in gray color. $\mathbf{B}$, zoom in of the Coquimbo region; the gray square represents the study area. The light gray lines are indicating the fourteen areas distributed in this region. C, map showing the locations where the elasmobranch fossils were found. The black dot represents the locations: 1, Caleta Chañaral; 2, Punta de Choros; 3, Caleta Hornos; 4, La Cantera Baja; 5, Quebrada El Culebrón; 6, Quebrada Las Rosas; 7, La Herradura; 8, El Rincón.

the root. Taxonomic identification included an extensive bibliographical review and comparative studies of fossil and extant specimens from: Museo Nacional de Historia Natural de Santiago (SGO-PV) in Chile, Museo Paleontológico de Caldera (MPC), Atacama, both in Chile and Natural History Museum of Basel (NMB), Switzerland; Paleontological collections of the Alcaldía Bolivariana de Urumaco (AMUCURS), Venezuela; Palaeontological Institute and Museum at the University of Zurich (PIMUZ), Switzerland.

\section{GEOLOGICAL SETTINGS}

Flat terraces of sedimentation characterize the Coquimbo Formation. These are composed of neritic or sublittoral marine sediments that are fine to medium-grained (Le Roux et al., 2004). Small-cemented yellowish sand is also present, along 
with blocks displaced from the bedrock. Shell middens are commonly found in banks between 0.40 and $2 \mathrm{~m}$ thickness, on the surface or in sectors with a whitish calcareous crust on the ground (Paskoff, 1970; Le Roux et al., 2004; Acosta et al., 2006). Although the shell middens are mostly from the Plio-Pleistocene, the Miocene transgression seems to be mostly responsible for most of the marine sediment (Le Roux et al., 2006). In this study, shark fossil teeth were obtained from areas near beaches such as marine terraces close to the sea or streams. The terraces have a relative distance of up to $2 \mathrm{~km}$ from the coastline and a peak height of 81 meters (Le Roux et al., 2006). Paskoff (1970) suggests a height of $80 \mathrm{~m}$ for the outcrop of the Miocene transgression, but some shark fossil teeth can be found in secondary deposits due to relief changes associated with neotectonics. These changes were very important in structuring the relief of the coast during the Plio-Quaternary (Radtke, 1989).

The age of the Coquimbo Formation could be extended backward in time to about $15 \mathrm{Ma}$ (middle Miocene). Fossil invertebrates suggest that all locations sampled in this study originated from Pliocene sedimentary depositions of marine fauna (Herm, 1969). A study based on the potassium-argon radioisotope suggests that the Coquimbo Formation is upper Miocene in age, of around 6 million years ago (Chávez et al., 2007). In addition, thirteen stratigraphic units were identified in the Coquimbo Formation using faunal remains and lithological features (Le Roux et al., 2004). A maximum age of 2 Ma was estimated using strontium from microfossil remains found in the top of the stratigraphic unit (middle Miocene to late Pliocene; Le Roux et al., 2004). The second stratigraphic unit is from Langhian sediment and it has associated with the base of the Coquimbo Formation (Le Roux et al., 2004; Acosta et al., 2006). As a result of these estimations, we propose an age close to the middle Miocenelate Pliocene for the Coquimbo Formation.

The stratigraphic sequence from Quebrada Las Rosas is composed of marine invertebrates and vertebrates (see Figure 2). The basal stratum comprised lime and clay with fossil mollusks and shark teeth. The median stratum is sandy and made of conglomerates of mollusks. The upper stratum is formed of fine sand with a layer of invertebrates. However, this is a general description and we are not able to provide further details because of the lack of stratigraphic studies. A similar formation is observed in Bahía Inglesa Formation (BIF) with common records of shark teeth composed of a large spectrum of taxa (Suárez \& Marquardt, 2003; Rivadeneira \& Varas, 2012).

\section{SYSTEMATIC PALEONTOLOGY}

Order LAMNIFORMES Berg 1937

Family †OTODONTIDAE Glikman, 1964

$\dagger$ Carcharocles Jordan \& Hannibal, 1923

$\dagger$ Carcharocles megalodon (Agassiz, 1843)

(Figures 3A-C)
Material. Four lower lateral teeth (MNHN SGO. 58, Coquimbo; MALS P-228, Punta de Choros; MALS P-6564, Quebrada Chañaral de Aceitunas; MALS P-227, Quebrada El Culebrón).

Description. Teeth have a triangular, broad and slightly symmetrical crown. The lingual face of the crown is flat and the labial is convex with a typical large neck, clearly observed in the specimen MNHN SGO. 58. The crown in the rest of the specimens is poorly preserved. Both cutting edges have a fine serration. The root has well developed lobes and a weak lingual protuberance. The teeth range in height between 32 and $98 \mathrm{~mm}$ and width between 35 to $93 \mathrm{~mm}$. The largest tooth is the specimen MALS P-228, with $98 \mathrm{~mm}$ in height and 93 $\mathrm{mm}$ in width.

Remarks. Carcharocles was a cosmopolitan species and its fossil record has been reported from almost all Neogene sedimentary deposits that contain shark teeth (García et al., 2009). In the Neogene deposits, Carcharocles is mainly represented by $C$. chubutensis Ameghino, 1901 and C. megalodon Agassiz, 1843 (e.g. Pimiento et al., 2010, 2013a,b; Cappetta, 2012; Pimiento \& Clements, 2014). C. megalodon has a stratigraphic range from the middle Miocene to the late Pliocene (Pimiento \& Clements, 2014), whereas $C$. chubutensis has been restricted to the early/ middle Miocene (Pimiento \& Clements, 2014). However, taxonomical distinctions and generic identification between the taxa have been debated over the years. The classification of Carcharocles linage is still discussed (Pimiento et al., 2010, 2013b; Reinecke et al., 2011; Cappetta, 2012; Bor et al., 2012). From the Neogene of Chile, C. megalodon has been reported from the Bahía Inglesa and Lo Abarca formations (Long, 1993; Walsh, 2001; Encinas, 2002; Suárez \& Encinas, 2002; Suárez et al., 2004). Philippi (1887) reported an isolated tooth of C. megalodon with unclear origin from Coquimbo region. The specimens of $C$. megalodon from the Coquimbo Formation extend the southern distribution on the Eastern Pacific during the late Neogene. An overview of the C. megalodon is show by Carrillo-Briceño et al. (2013) from America fossil records.

Family LAMNIDAE Müller \& Henle, 1838

Carcharodon Smith in Müller \& Henle, 1838

Carcharodon carcharias Linnaeus, 1758

(Figure 4A)

Material. Fifty upper lateral teeth (MALS P-59, MALS P-60, MALS P-64, Quebrada El Culebrón; MALS P-79, MALS P-80, MALS P-83, MALS P-84, MALS P-86, MALS P-87, MALS P-88, MALS P-90, MALS P-92, MALS P-105, La Cantera Baja; MALS P-119, MALS P-126, MALS P-127, Quebrada Las Rosas; MALS P-131, MALS P-133, Caleta Chañaral; MALS P-142, MALS P-143, MALS P-144, MALS P-150, MALS P-151, MALS P-152, MALS P-159, MALS P-160, MALS P-161, MALS P-163, MALS P-164, MALS P-165, MALS P-166, MALS P-169, MALS P-170, 


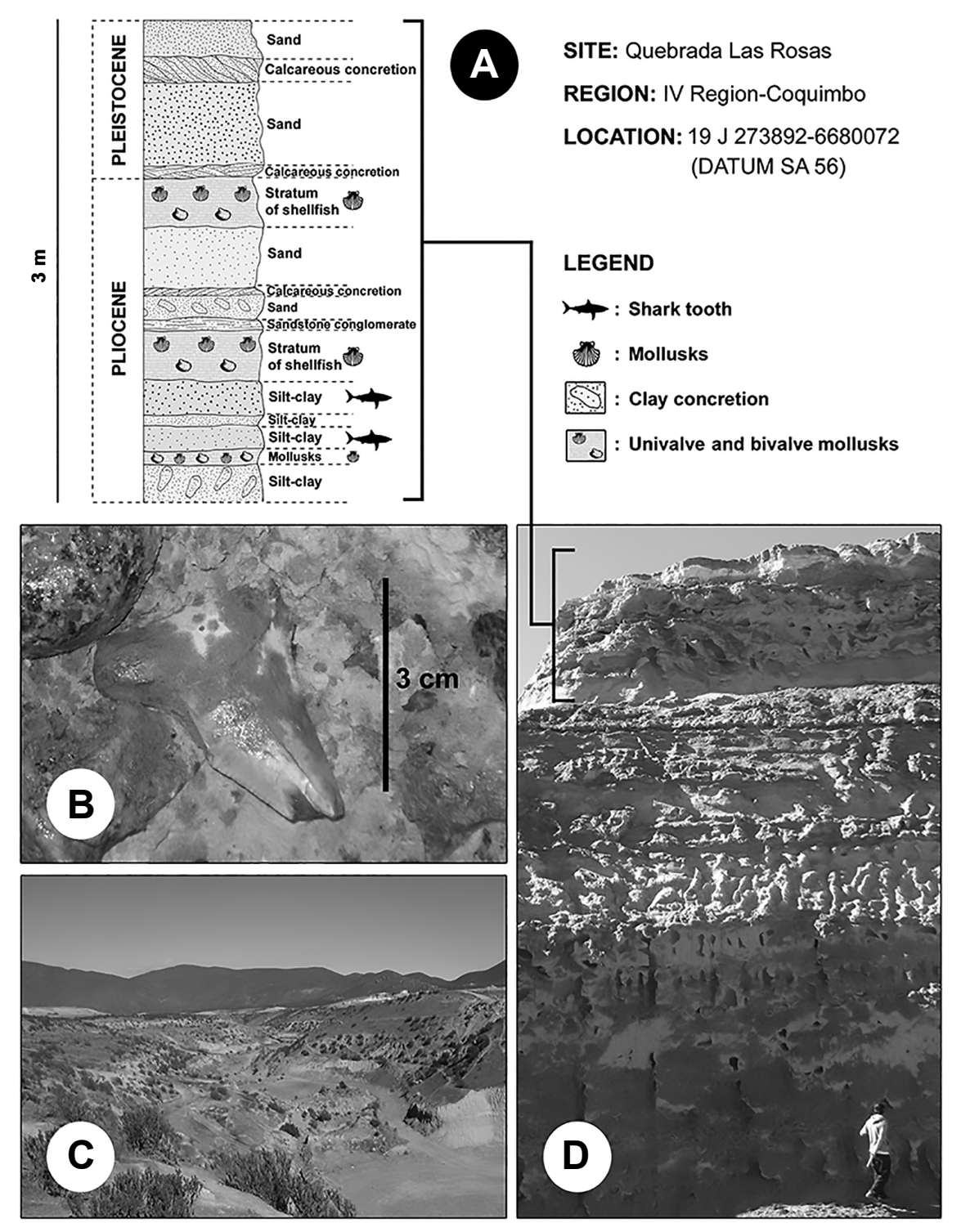

Figure 2. A, geological stratigraphic units showing the association of elasmobranchs found in the Coquimbo Formation. B, Carcharodon carcharias fossil tooth found on silt-clay mixed with stones and sedimentary soil. C, landscape of sedimentary terraces of the Coquimbo Formation located in Quebrada Las Rosas. D, general view of stratigraphic units from Quebrada Las Rosas.
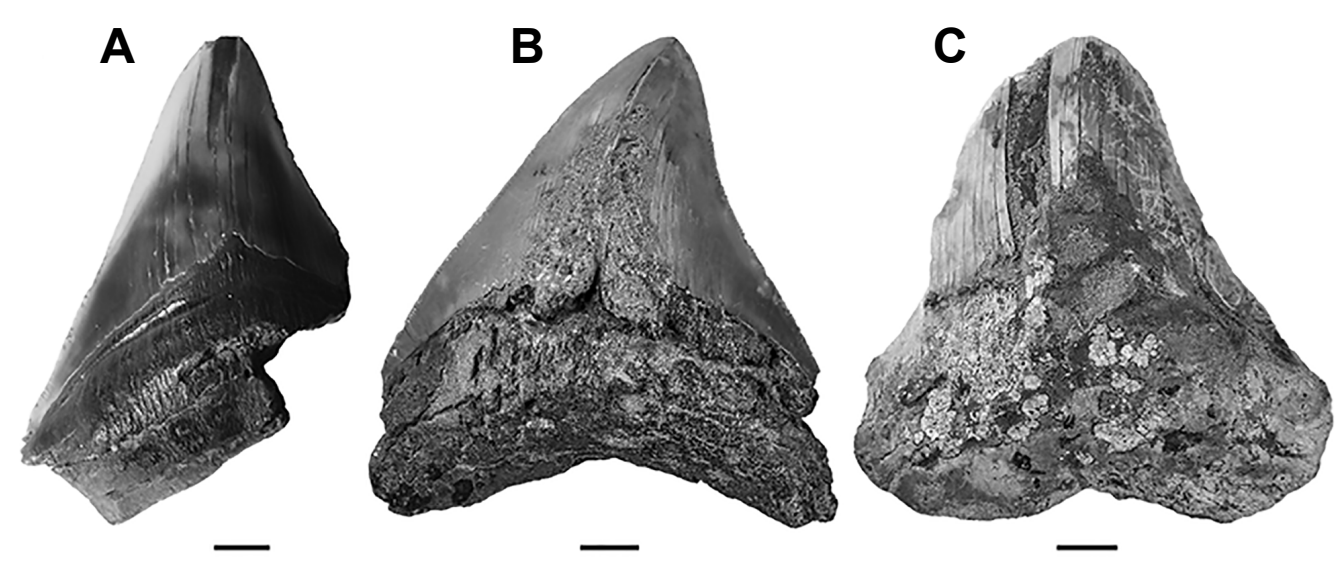

Figure 3. Carcharocles megalodon fossil teeth. A, MNHN SGO.58, lower lateral tooth in labial view; B, MALS P-6564, lower lateral tooth in labial view; C, MALS P-228, lower lateral in labial view. Scale bars $=10 \mathrm{~mm}$. 

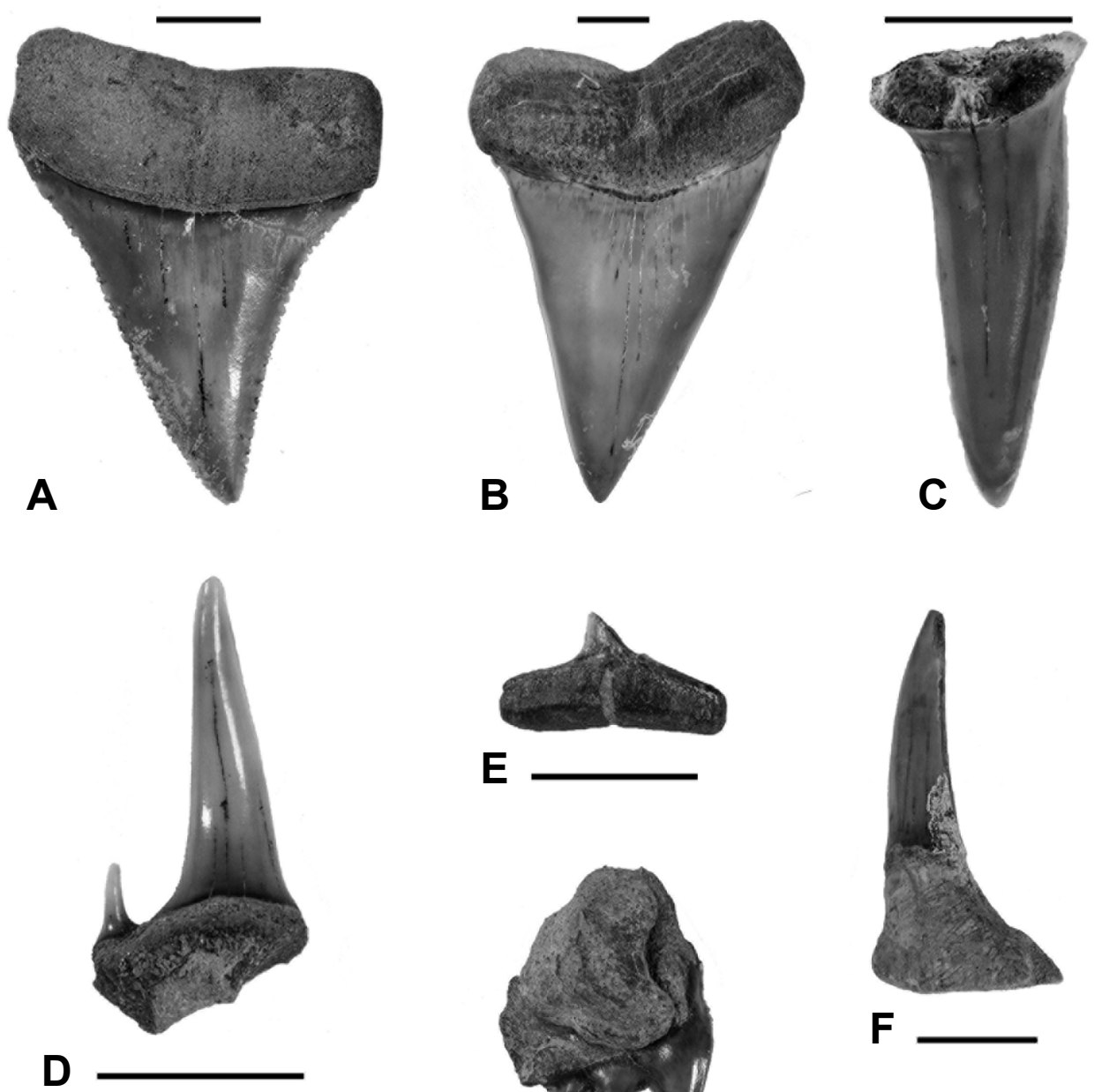

E
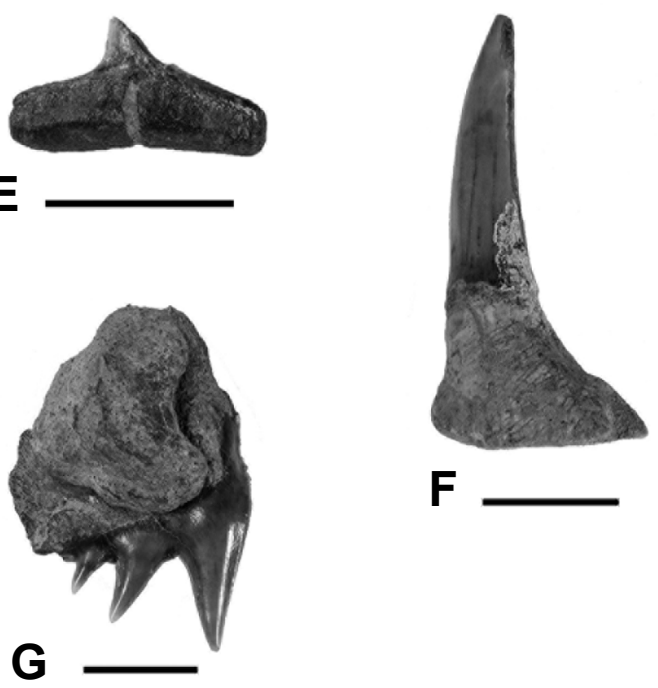

$\mathbf{F}$

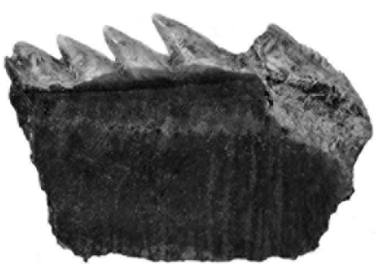

H

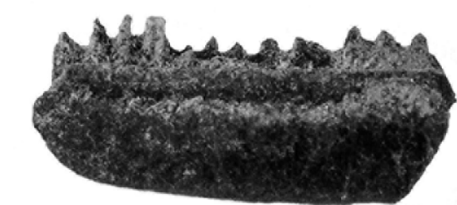

I

Figure 4. Elasmobranch fossil teeth. A, Carcharodon carcharias, MALS P-87, upper lateral tooth in labial view. B, Carcharodon plicatilis, MALS P-63, upper lateral tooth in labial view. C, Isurus cf. I. oxyrinchus, MALS P-199, upper anterior tooth in labial view. D, Odontaspis ferox, MALS P-104, lateral tooth in labial view. E, Carcharhinus sp. MALS P-111, lower lateral tooth in labial view. F, Pristiophorus sp., MALS P-75, rostral tooth. G, Hexanchus cf. H. griseus, MALS P-108, upper anterior tooth in lingual view. H, Hexanchus cf. H. griseus, MALS P-225, lower lateral tooth in lingual view. I, Myliobatis sp., MALS P-231, symphysial tooth of in lingual view. Scale bars $=10 \mathrm{~mm}$.

MALS P-176, MALS P-177, MALS P-178, MALS P-179, MALS P-184, MALS P-189, MALS P-190, MALS P-193, MALS P-197, MALS P-198, La Herradura; MALS P-203, MALS P-206, MALS P-208; MALS P-212, MALS P-216, MALS P-217, MALS P-219, Quebrada El Culebrón), one upper posterior tooth (MALS P-114, La Cantera Baja), three upper teeth (MALS P-147, MALS P-181, MALS P-185, La Herradura), ten upper anterior teeth (MALS P-85, MALS P-93, La Cantera Baja; MALS P-116, Quebrada Las Rosas; MALS P-146, MALS P-155, MALS P-186, MALS P-191,
MALS P-194, La Herradura; MALS P-210, MALS P-220, Quebrada El Culebrón), three lower posterior teeth (MALS P-78, MALS P-113, La Cantera Baja; MALS P-148, La Herradura), fourteen lower lateral teeth (MALS P-81, MALS P-82, MALS P-91, La Cantera Baja; MALS P-129, MALS P-130, Quebrada Las Rosas; MALS P-145, MALS P-149, MALS P-171, MALS P-196, La Herradura; MALS P-207, MALS P-209, MALS P-211, MALS P-2014, MALS P-215, Quebrada El Culebrón), six lateral teeth (MALS P-117, MALS P-128, Quebrada Las Rosas; MALS P-153, MALS 
P-162, MALS P-173, La Herradura; MALS P-223, Quebrada El Culebrón), twenty lower anterior teeth (MALS P-89, La Cantera Baja; MALS P-141, MALS P-154, MALS P-156, MALS P-168, MALS P-172, MALS P-174, MALS P-180, MALS P-182, MALS P-183, MALS P-192, MALS P-195, La Herradura; MALS P-204, MALS P-205, MALS P-213, MALS P-218, MALS P-221, MALS P-222, MALS P-224, Quebrada El Culebrón) and one unknown position tooth (MALS P-157, La Herradura).

Description. Upper and lower teeth have a broad, triangular and slightly elongated labio-lingually compressed crown. The labial face is flattened whereas the lingual is convex; both cutting edges are coarse serrated. The basal portion of the crown is in contact with roots and lacks enamel, forming a thin dental band, observable on the labial and lingual surface. Root with two well-defined lobes that are straight or it may present a U-shaped arch in some specimens. The teeth range in height between 10 and $73 \mathrm{~mm}$ and width between 10 to $47 \mathrm{~mm}$.

Remarks. The fossil record of Carcharodon carcharias is known from the lower Pliocene to recent, and it has been referred to Africa, Asia, Australia, Europa and North and South America (Kemp, 1991; Cappetta, 2012; Ehret et al., 2012, Cione et al., 2012; Carrillo-Briceño et al., 2013). The fossil record of $C$. carcharias from the late Neogene of Chile is abundant, mainly from the Pliocene strata of the Bahía Inglesa Formation (Long, 1993; Walsh, 2001; Quilodran \& Marquardt, 2001; Walsh \& Naish, 2002; Suárez \& Marquardt, 2003). However, some specimens have been dubiously referred to the late Miocene strata of this unit (e.g. Bianucci et al., 2006). Other fossil record of C. carcharias from Chile include the following localities: Bahía Salado, Bahía Tongoy, Cuenca del Tiburon, Horcón, La Cueva, and La Portada (Suárez \& Brito, 2000; Emslie \& Correa, 2003; Suárez \& Marquardt, 2003; Le Roux et al., 2006; Carrillo-Briceño et al., 2013). Cione et al. (2012) and Carrillo-Briceño et al. (2013) provided a summary of the fossil record of $C$. carcharias in South America.

\section{$\lceil$ Carcharodon plicatilis Agassiz, 1843}

(Figure 4B)

Material. Upper lateral tooth (MALS P-63, El Rincón). Description. The tooth has a wide, triangular and labiolingually compressed crown. The cutting edges are sharp without any serration. The root is compressed with two lobes, and the base shows a concavity forming an inverted V. The tooth measures $50 \mathrm{~mm}$ in height and $36 \mathrm{~mm}$ in width.

Remarks. Several morphological aspects of the taxonomic classification of this species have been debated over the years, without consensus (e.g. Purdy et al., 2001; Cappetta, 2012; Cione et al., 2012; Ehret et al., 2012). Previous taxonomic assignments have included some species of "wide-toothed shape" such as Isurus planus Agassiz, 1856, Isurus hastalis Agassiz, 1838 and Isurus xiphodon Agassiz, 1838 to Cosmopolitodus (Cappetta, 2006, Cione et al., 2012). Ehret et al. (2012) included Cosmopolitodus to
Carcharodon, proposing a transition between Carcharodon hastalis and Carcharodon carcharias. Ward \& Bonavia (2001) suggested the recognition of only one species, and proposed that C.xiphodon is a nomen dubium because of the uncertainty implied in differentiating Cosmopolitodus hastalis from Cosmopolitodus xiphodon. According to Cione (1988), Purdy et al. (2001) and Cione et al. (2012), there is a species that appears to be the putative sister group of Carcharodon carcharias and different from Cosmopolitodus hastalis. Cione et al. (2012) proposed this species as "Isurus" plicatilis Agassiz, 1843, which is recognized as an available and valid taxon. According to Cione et al. (2012), only plicatilis or xiphodon [adapting latter from Purdy et al. (2001)] should be referred to the genus Carcharodon. Hereby, we adopt the taxonomic proposal suggested by Cione (1988) and Cione et al. (2012). In the Neogene of Chile, Carcharodon plicatilis has been reported from the Bahía Inglesa, Navidad and Coquimbo formations (Long, 1993; Quilodran \& Marquardt, 2001; Walsh, 2001; Suárez \& Encinas, 2002; Walsh \& Naish, 2002; Suárez \& Marquardt, 2003; Le Roux et al., 2006).

\section{Isurus Rafinesque, 1810}

Isurus cf. oxyrinchus Rafinesque, 1810 (Figure 4C)

Material. Upper lateral tooth (MALS P-58, Caleta Chañaral), upper anterior tooth (MALS P-199, Caleta de Hornos), lower anterior tooth (MALS P-134, Caleta Chañaral) and anterior tooth, unknown jaw position (MALS P-188, La Herradura). Description. Three teeth are incomplete with damaged roots (MALS P-134, MALS P-188, MALS P-199). In anterior teeth the crown is elongated, asymmetrical, distally inclined and with smooth sharp cutting edges; its apex is sharp-pointed. The lateral has a triangular crown slightly inclined distally. There is an evident lingual protuberance with a transverse groove. The only complete tooth (MALS P-58) measures 25 $\mathrm{mm}$ in height and $12 \mathrm{~mm}$ in width.

Remarks. Isurus oxyrinchus has a stratigraphic record from the late Oligocene to present with a cosmopolitan paleodistribution (Reinecke, 2011). Despite the fact that the specimens from the Coquimbo Formation are mostly incomplete, they exhibit a close resemblance to teeth of the extant $I$. oxyrinchus, allowing the association of the fossils with this taxon. In Chile, the fossil record of I. oxyrinchus appears regularly along the central coast of the Bahía Inglesa Formation (Suárez et al., 2002; Walsh, 2001; Long, 1993; Suárez \& Marquardt, 2003; Suárez et al., 2004). In contrast to Bahía Inglesa, I. oxyrinchus fossil teeth are less frequent southward. However, this species has been found in marine sediments from Lo Abarca, Navidad and Horcón formations (Encinas, 2002; Suárez \& Encinas, 2002; Suárez \& Marquardt, 2003; Suárez et al., 2006; Carrillo-Briceño et al., 2013). 
Family ODONTASPIDIDAE Müller \& Henle, 1839

\author{
Odontaspis Agassiz, 1838 \\ Odontaspis ferox Risso, 1810
}

(Figure 4D)

Material. Lateral tooth (MALS P-104, La Cantera Baja). Description. The crown is elongated and slender with sharp and smooth cutting edges. Fossil and extant specimens of Odontaspis ferox show between three and one lateral cusplets (e.g. Purdy et al., 2001). However, the specimen MALS P-104 preserves only one cusplet as a consequence of the damaged root. The root shows an evident lingual protuberance. The incomplete tooth is $22 \mathrm{~mm}$ in height.

Remarks. Odontaspis ferox has a fossil record from the Miocene to recent (Purdy et al., 2001; Aguilera \& Rodríguez de Aguilera, 2001; Marsili, 2007). During the Paleocene-Eocene, this species is considered as the dominant group of Patagonia of Chile and Argentina, as well as of other ancient temperate seas around the world (e.g. Eocene of Seymour Island, Antarctica) (Arratia \& Cione, 1996). This species has been reported to the Bahía Inglesa (Suárez et al., 2002) and Navidad formations (Suárez\& Encinas, 2002; Suárez \& Marquardt, 2003).

\section{Order CARCHARHINIFORMES Compagno, 1973 Family CARCHARHINIDAE Jordan \& Evermann, 1896}

Carcharhinus Blainville, 1816

Carcharhinus sp.

(Figure 4E)

Material. Three lower lateral teeth (MALS P-110, MALS P-112, La Cantera Baja; MALS P-111, La Cantera).

Description. The fossil teeth are fragmented, preserving only the crown or the root. The crown is triangular and decreases in size toward the apex of the tooth. The crown is distally inclined towards the right with fine serration along the cutting edges (MALS P-110). The root has broad lobes with slightly basal concavity and a shallow nutritive groove (MALS P-111). Diagnostic characters of the species are difficult to identify because of the fragmented condition and poor preservation of the specimens.

Remarks. Morphological features of the tooth within the genus Carcharhinus closely resembles between species. This confusion makes difficult the taxonomic classification of the carcharhinids fossil teeth, especially when they are incomplete and eroded. At least two species have been identified from Chilean marine sediments i.e. Carcharhinus albimarginatus (Rüppell, 1837) (Long, 1993; Suárez \& Marquardt, 2003) and Carcharhinus brachyurus (Günther, 1870) (Suárez et al., 2002; Suárez et al., 2004; Carrillo-Briceño et al., 2013). However, previous studies in modern species have confirmed the presence of other carcharhinids species in Chilean coast. Pequeño \& Saez (2003) have reported the presence of Carcharhinus galapagensis (Snodgrass \& Heller, 1905) from Salas y Gomez
Island and Hernández et al. (2008) identified the species Carcharhinus obscurus (Lesueur, 1818) from shark fins traded in Chilean market. According to these antecedents, the presence of extinct and modern carcharhinids should be better studied in Chile because there are uncertainly in some of the species used to occur and/or still found in Chilean coast. In the Neogene and Quaternary of Chile, species of genus Carcharhinus has been reported from the Miocene and Pliocene in the Bahía Inglesa Formation (Long, 1993; Walsh, 2001; Suárez \& Marquardt, 2003; Suárez et al., 2002), Bahía Salado (Suárez \& Brito, 2000), Cuenca del tiburón (Emslie \& Correa, 2003; Suárez \& Marquardt, 2003), La Portada (Suárez \& Marquardt, 2003) and Horcón (Carrillo-Briceño et al., 2013).

Order PRISTIOPHORIFORMES Berg, 1958

Family PRISTIOPHORIDAE Bleeker, 1859

Pristiophorus Müller \& Henle, 1837

Pristiophorus sp.

(Figure 4F)

Material. Thirteen rostral teeth (MALS P-69, MALS P-70, MALS P-71, MALS P-72, MALS P-73, MALS P-74, MALS P-75, MALS P-76, MALS P-77, La Cantera Baja; MALS P-118, Quebrada Las Rosas; MALS P-138, MALS P-139, MALS P-140, La Herradura).

Description. The rostral teeth are elongated and slender, with a dorso-ventrally compressed crown. The cutting edges are smooth and without serration. The root is robust with a flat base and is wider than the crown. The root also has a conical shape with the widest part being the base. Most of the specimens are complete and measure between 31 and $32 \mathrm{~mm}$ in length.

Remarks. Pristiophorus is known from the upper Cretaceous to present (Cappetta, 2012). The Neogene fossil record of Pristiophorus showed a wide paleobiogeographic distribution in America (Carrillo-Briceño et al., 2015). Nowadays, there is only one species in America Pristiophorus schroederi Müller and Henle, 1837, which is distributed in the Bahamas region, Western Central Atlantic (Compagno et al., 2005). The taxonomy of the fossil species of Pristiophorus found in the Americas, and especially the rostral teeth have been poorly studied. For this reason we prefer to keep the Pristiophorus specimen from the Coquimbo Formation in open nomenclature. The fossil record of Pristiophorus in Chile includes Bahía Inglesa (Walsh, 2001; Suárez et al., 2002), Navidad (Suárez \& Encinas, 2002; Suárez et al., 2006), Horcón (Carrillo-Briceño et al., 2013) and La Cueva formations (Suárez \& Marquardt, 2003).

Order HEXANCHIFORMES Buen, 1926 Family HEXANCHIDAE Gray, 1851

\section{Hexanchus Rafinesque, 1810}

Hexanchus cf. griseus (Figures 4G-H) 
Material. Five upper teeth (MALS P-107, MALS P-108, La Cantera Baja; MALS P-125, Quebrada Las Rosas; MALS P-61, MALS P-226, Quebrada el Culebrón) and a lower lateral tooth (MALS P-109, La Cantera Baja; MALS P-225, Quebrada el Culebrón).

Description. Upper teeth are elongated acrocones that are distally inclined, with two or five distally directed cusplets. The root is flattened and subquadrangular. The lower tooth is incomplete with a missing acrocone (MALS P-225). However, five small and distally directed cusplets are present. The complete teeth range between 16 and $21 \mathrm{~mm}$ in height and between 8 to $18 \mathrm{~mm}$ in width.

Remarks. Hexanchus griseus is known from the Miocene to the recent (Cione \& Reguero, 1994). In Chile, Hexanchus griseus and Hexanchus sp. have been referred to the Bahía Inglesa and Horcón formations (Long, 1993; Walsh, 2001; Suárez \& Marquardt, 2003; Carrillo-Briceño et al., 2013). Suárez \& Marquardt (2003) referred isolated teeth of Hexanchus associated with cetacean remains from phosphatic layer in Caleta Inglesa and Bahía Chañaral. Arratia \& Cione (1996) and Carrillo-Briceño et al. (2013) presented a brief summary of the fossil record of Hexanchus in South America.

\section{Order MYLIOBATIFORMES Compagno 1973 Family MYLIOBATIDAE Bonaparte 1838}

\section{Myliobatis Cuvier, 1816}

Myliobatis sp.

(Figure 4I)

Material. Six isolated teeth (MALS P-66, MALS P-230, MALS P-231, MALS P-232, MALS P-233, MALS P-234, La Cantera Baja).

Description. The specimens consist of complete isolated teeth of the median files. These teeth are broader than long, with a slightly curved hexagonal contour. In all teeth the crown is practically flat with a smooth occlusal surface. Labial and lingual faces are slightly ornamented. The root displays vascularization type polyaulacorhize. The teeth are between 30 and $50 \mathrm{~mm}$ wide.

Remarks. The fossil record of Myliobatis extends worldwide from the Paleocene to present (Cappetta, 2012). The taxonomic identification of the isolated teeth of Myliobatis is extremely difficult because of the high dental variation within this group (Welton \& Zinsmeister, 1980; Nishida, 1990). For this reason, a specific taxonomic assignation was not possible and we assigned all specimens from the Coquimbo Formation to Myliobatis sp. In the Neogene of Chile, the genus Myliobatis has been found in the Bahía Inglesa, La Cueva and Navidad formations (Walsh, 2001; Suárez \& Marquardt, 2003; Suárez et al., 2004; Suárez et al., 2002). Summary of the fossil record of Myliobatis is discussed in Carrillo-Briceño et al. (2013).

\section{DISCUSSION}

Our results revealed at least nine elasmobranch taxa present during the Neogene at the Coquimbo Formation. These include Carcharocles megalodon, Carcharodon carcharias, C. plicatilis, Isurus cf. I. oxyrinchus, Pristiophorus sp., Odontaspis ferox, Carcharhinus sp., Hexanchus cf. $H$. griseus and Myliobatis sp. Of these species, C. megalodon, C. plicatilis, C. carcharias and I. oxyrinchus have been previously reported from the Coquimbo Formation (e.g. Philippi, 1887; Long, 1993; Suárez \& Marquardt, 2003; Le Roux et al., 2006). According to our results, Odontaspis ferox and Pristiophorus sp. represent the first fossil records for the Coquimbo Formation, although Long (1993) included two further species, Cetorhinus maximus and Aetobatus sp. for this locality. Our assemblage includes at least two extinct species: C. megalodon and C. plicatilis. With the exception of Pristiophorus sp., the rest of the elasmobranch taxa found in this study are related to the living species distributed along the Pacific coast of South America (e.g. Egaña \& McCosker, 1984; Acuña et al., 2002; Hernández \& Lamilla, 2004; Hernández et al., 2008).

The Neogene is characterized as a period of intense climatic, tectonic and biotic change (Zachos, 2001; Dekens et al., 2007; Dowsett \& Robinson, 2009; Garreaud et al., 2010). For instance, events such as the hyper-aridity of the Atacama Desert and the reactivation of the modern flow of the Humboldt Current produced important changes in the Neogene climate conditions (Garreaud et al., 2010; Tsuchi, 2002). Studies of elasmobranch fossils suggest vast variations in species richness in the South Pacific (Villafaña \& Rivadeneira, 2014). The elasmobranch fossil record of the Coquimbo Formation would suggest differences in the dynamics of elasmobranch biodiversity. Species, such as Carcharocles megalodon, Carcharodon plicatilis and Pristiophorus sp. probably became extinct due to climatic and biotic changes that occurred during the late Neogene. Rivadeneira \& Marquet (2007) suggested that the diversity in the composition of mollusk species decreased during the Miocene and Pliocene along the South American Pacific coast. A similar tendency in decreasing diversity was shown with the extinction of marine mammals (Valenzuela-Toro et al., 2013), and sea birds (Chávez et al., 2007). The extinction of several macro-vertebrates may reflect the macro-evolutionary dynamics of those taxa in the temperate Pacific coast of South America.

In addition, we found differences in the distribution of extinct elasmobranch species in comparison to modern species. For example, the fossil distribution of Carcharodon carcharias and Hexanchus increased southward (Villafaña \& Rivadeneira 2013). In contrast, the presence of shark species such as Isurus oxyrinchus, Odontaspis ferox, Carcharhinus sp. and Myliobatis sp. decreased southward (Villafaña \& Rivadeneira 2013). Analyzing the distribution of genus Carcharias in the South Pacific Ocean, it might be attributed to the abrupt temperature decrease during the middle Pliocene and Pleistocene (Cione et al., 2007). This change in the temperature eventually also affected the 
distribution other species. However, Villafaña \& Rivadeneira (2013) suggested that the fluctuation in elasmobranch biodiversity might also be explained by ecological and life history aspects such as body size, modes of reproduction, and migration patterns.

In order to explain the variability in richness and composition of marine fossil records in Chile, it would be valuable to increase the sampling effort of fossil records from the Coquimbo Formation and other Neogene units. Furthermore, more sampling sites should be determined and reviewed. The well-preserved sedimentary sequence of the Coquimbo Formation is an unexplored field. A better description of the elasmobranch fossil records will set the baseline to gain a better understanding of the ecology, distribution and evolution of taxa that ranged the oceans millions of years ago.

\section{ACKNOWLEDGMENTS}

We would like to thank several people from the MALS for their friendly help and collaboration in this research. The manuscript was greatly improved by the very constructive comments and suggestions made by A.L. Cione and G. Cuny. Thank to V. Castelletto for taking photographs for this study, and also thank to M. Heidemeyer and J. Neenam for the proof editing of the manuscript.

\section{REFERENCES}

Acosta, C.H.; Canto, J. \& Tambussi, C. 2006. Pingüinos (Aves, Spheniscidae) en Coquimbo (Mioceno medio-Plioceno tardío), Chile y su vinculación con las corrientes oceánicas. Revista Española de Paleontología, 21:115-121.

Acuña, E.; Villaroel, J.C. \& Grau, R. 2002. Fauna ictica asociada a la pesqueria de pez espada (Xiphias gladius Linnaeus). Gayana, 66:263-267. doi:10.4067/S0717-65382002000200025

Agassiz, L. 1833-1843. Recherches sur les poissons fossiles. Volume 3, Neuchatel, p. 390.

Agassiz, L. 1856. Notice on the fossil fishes found in California by Blake, W.P. American Journal of Science and Arts, 21:272-275.

Aguilera, O. \& Rodríguez de Aguilera, D. 2001. An exceptional coastal upwelling fish assemblage in the Caribbean Neogene. Journal of Paleontology, 75:732-742. doi: 10.1666/0022-3360(2001)075<0732:AECUFA>2.0.CO;2

Alván, A.; Apolín, J. \& Chacaltana, C. 2004. Los dientes de Seláceos (Condrichthyes) y su aplicación estratigráfica en Las Lomas de Ullujaya (Ica, Perú). In: CONGRESO PERUANO DE GEOLOGÍA, 13, 2004. Resúmenes Extendidos, Lima, p. 595-598.

Ameghino, F. 1901. L'âge des formations sédimentaires de Patagonie. Anales de la Sociedad Cientifica Argentina, 51:20-39, 65-91.

Arratia, G. \& Cione, A.L. 1996. The fish fossil record of southern South America. In: G. Arratia (ed.) The vertebrate fossil record of southern South America, Münchener Geowissenschaft Abhanlungen, p. 565-593.

Balboltin, F. \& Reyes, E. 1981. Ataque de tiburón registrado en la costa de Chile Central. Noticiero Mensual del Museo Historia Natural, 298:3-7.
Beal, C.H. 1948. Reconnaissance of the geology and oil possibilities of Baja California, Mexico. Geological Society of America Memoir, 31:1-150. doi:10.1130/mem31

Berg, L.S. 1937. A classification of fish-like vertebrates. Bulletin of the Academy of Sciences of the USSR, 1937:1277-1280.

Berg, L.S. 1958. System der rezenten und fossilen Fischartigen und Fische. Berlin, Verlag Wissenschaften, 310 p.

Bianucci, G.; Sorbi, S.; Suárez, M. \& Landini, W. 2006. The southernmost sirenian record in the Eastern Pacific Ocean, from the late Miocene of Chile. Comptes Rendus Palevol, 5:945-952. doi:10.1016/j.crpv.2006.06.001

Blainville, H.M.D. 1816. Prodrome d'une nouvelle distribution systematique du regne animal. Bulletin de la Societé Philomathique de Paris, 8:105-112, 121-124.

Bleeker, P.R. 1859. Enumeratio specierum piscium hucusque in Archipelago indico observatarum. Acta Societatis Scientiarum Indo-Neerlandae, 6:1-276.

Bonaparte, C.L. 1838. Selachorum tabula analytica. Nuovi Annali della Science Naturali Bologna, 1:195-214.

Bor, T.; Reinecke, T. \& Verschueren, S. 2012. Miocene Chondrichthyes from Winterswijk-Miste, the Netherlands. Palaeontos, 21:1-136.

Boreske, J.R.; Goldberg, L. \& Cameron, B. 1972. A reworked cetacean with clam borings: Miocene of North Carolina. Journal of Paleontology, 46:130-139.

Campbell, H.J.; Andrews, P.B.; Beu, A.G.; Maxwell, P.A.; Edwards, A.R.; Laird, M.G.; Hornibrook, N.B.; Mildenhall, D.C.; Watters, W.A.; Buckeridge, J.S.; Lee, D.E.; Strong, C.P.; Wilson, G.J. \& Hayward, B.W. 1993. Cretaceous-Cenozoic geology and biostratigraphy of the Chatham Islands, New Zealand. Institute of Geological and Nuclear Sciences Monograph, 2:1-269.

Cappetta, H. 1970. Les Sélaciens du Miocène de la région de Montpellier. Montpellier, Laboratoire de Paléontologie, 139 p.

Capetta, H. 1980. Les selaciens du Cretacesuperieur du Liban. II: Batoides. Palaeontolographica A, 168:149-229.

Cappetta, H. 1987. Chondrichthyes II-Mesozoic and Cenozoic Elasmobranchii. Handbook of Paleoichthyology. New York, Verlag, $193 \mathrm{p}$.

Cappetta, H. 2006. Elasmobranchii post-Triadici (index generum et specierum). In: W. Riegraf (ed.) Fossilium Catalogus I: Animalia, Backhuys Publish, p. 472.

Cappetta, H. 2012. Chondrichthyes II: Mesozoic and Cenozoic Elasmobranchii: Teeth. In: H.P. Schultze (ed.) Handbook of Paleoichthyology, Verlag, p. 512.

Carrillo-Briceño, J.D.; De Gracia, C.; Pimiento, C.; Aguilera, O.A.; Kindlimann, R.; Santamarina, P. \& Jaramillo, C. 2015. A New Late Miocene Chondrichthyan assemblage from the Chagres Formation, Panama. Journal of South America Earth Science, 60:56-70. doi:10.1016/j.jsames.2015.02.001

Carrillo-Briceño, J.D.; González-Barba, G.; Landaeta, M.F. \& Sven, N. 2013. Condrictios del Plioceno superior de la Formación Horcón, Región de Valparaíso, Chile central. Revista Chilena de Historia Natural, 86:191-206. doi:10.4067/s0716-078x2013000200008

Chávez, M.F. 2008. La ornitofauna de la Formación Bahía Inglesa, Caldera, Chile. Escuela de Ciencias, Universidad Austral de Chile, Tesis de grado, $162 \mathrm{p}$.

Chávez, M.; Stucchi, M. \& Urbina, M. 2007. El registro de Pelagornithidae (Aves: Pelecaniformes) y la avifauna Neógena del Pacífico sudeste. Boletín del Instituto Francés de Estudios Andinos, 36:175-197. doi:10.4000/bifea.3780

Cione, A.L. 1988. Los peces de las formaciones marinas del Cenozoico de Patagonia. Facultad de Ciencias Naturales y Museo, Universidad Nacional de La Plata, Thesis Doctoral, 536 p. 
Cione, A.L.; Cabrera, D. \& Barla, M.J. 2012. Oldest record of the great white shark (Lamnidae, Carcharodon; Miocene) in the Southern Atlantic. Geobios, 45:167-172. doi:10.1016/j. geobios.2011.06.002

Cione, A.L.; Mennucci, J.A.; Santalucita, F. \& Acosta-Hospitaleche, C. 2007. Local extinction of sharks of genus Carcharias Rafinesque, 1810 (Elasmobranchii, Odontaspididae) in the Eastern Pacific Ocean. Revista Geológica de Chile, 34:139-145. doi:10.4067/s0716-02082007000100007

Cione, A.L. \& Reguero, M.A. 1994. New records of the sharks Isurus and Hexanchus from the Eocene of Seymour Island, Antarctica. Proceedings of the Geologists' Association, 105:1-14. doi:10.1016/s0016-7878(08)80134-4

Compagno, L.J.V. 1973. Interrelationships of living elasmobranchs. In: P.H. Greenwood; C. Patterson \& H. Miles (eds.) Interrelationships of fishes, Zoological Journal of the Linnean Society, p. 15-61.

Compagno, L.J.V. 1977. Phyletic relationships of living sharks and rays. American Zoologist, 17:303-322. doi:10.1093/icb/17.2.303

Compagno, L.J.V. 1984. Sharks of the world. An annotated and illustrated catalogue of shark species known to date. FAO Fisheries Synopsis, 125:1-249.

Compagno, L.J.V.; Dando, V.M. \& Flower, S. 2005. Sharks of the world. Princeton, Princeton University Press, 368 p.

Cope, E.D. 1868. An addition to the vertebrate fauna of the Miocene period, with a synopsis of the extinct Cetacea of the United States. Proceedings of the Academy of Natural Sciences of Philadelphia, 19:138-157.

Cuvier, G. 1816. Le Règne Animal Distribué D'après son Organisation Pour Servir de Base à L'histoire Naturelle des Animaux et D'introduction à L'anatomie Comparée. Les Reptiles, les Poissons, les Mollusques et les Annélides. Deterville. Paris, p. 532.

De Buen, F. 1926. Catálogo ictiológico del Mediterráneo español y de Marruecos. Resultados Campanas Internaccionale Institute Español Oceanografiá, 2: 153-161.

Dekens, P.S.; Ravelo, A.C. \& McCarthy, M.D. 2007. Warm upwelling regions in the Pliocene warm period. Paleoceanography, 22:112. doi:10.1029/2006PA001394

Dowsett, H.J. \& Robinson, M.M. 2009. Mid-Pliocene equatorial Pacific sea surface temperature reconstruction: a multi-proxy perspective. Philosophical Transactions of the Royal Society A, 367:109-125. doi:10.1098/rsta.2008.0206

Egaña, A.C. \& McCosker, J.E. 1984. Attacks on divers by white sharks in Chile. California fish and game, 70:173-179.

Ehret, D.J.; Hubbell, H. \& MacFadden, B.J. 2009. Exceptional preservation of the white shark Carcharodon (Lamniformes, Lamnidae) from the early Pliocene of Peru. Journal of Vertebrate Paleontology, 29:1-13. doi:10.1671/039.029.0113

Ehret, D.J.; MacFadden, B.J.; Jones, D.S.; Devries, T.J.; Foster, D.A. \& Salas-Gismondi, R. 2012. Origin of the white shark Carcharodon (Lamniformes: Lamnidae) based on recalibration of the upper Neogene Pisco Formation of Peru. Paleontology, 55:1139-1153. doi:10.1111/j.1475-4983.2012.01201.x

Emslie, S.D. \& Correa, C.G. 2003. A new species of penguin (Spheniscidae: Spheniscus) and other birds from the late Pliocene of Chile. Proceedings of the Biological Society of Washington, 116:308-316.

Encinas, A. 2002. Presencia de vertebrados marinos neógenos en la Formación Lo Abarca, Chile Central. In: CONGRESO LATINOAMERICANO DE PALEONTOLOGÍA DE VERTEBRADOS, 1, 2002. Actas, Santiago, p. 32.
Fitzgerald, E.M.G. 2004. The fossil record of cetaceans (Mammalia) on the Australian continent. The Fossil Collector, 72:5-32.

García, E.X.M.; Antunes, M.T.; Balbino, A.C.; Ruiz-Muñoz, F. \& Civis-Llovera, J. 2009. Los tiburones Lamniformes (Chondrichthyes, Galeomorphii) del Plioceno inferior de la Formación Arenas de Huelva, suroeste de la cuenca del Guadalquivir, España. Revista Mexicana de Ciencias Geológicas, 26:674-686.

Garreaud, R.D.; Molina, A. \& Farias, M. 2010. Andean uplift, ocean cooling and Atacama hyperaridity: a climate modeling perspective. Earth and Planetary Science Letters, 292:39-50. doi:10.1016/j.epsl.2010.01.017

Gigoux, E. 1944. Fósiles de Atacama. Boletín del Museo Nacional de Historia Natural, 22:45-48.

Glikman, L.S. 1964. Sharks of the Paleogene and their stratigraphic significance. Moscow, Nauka Press, 229 p.

Gray, J. 1851. List of the specimens of fish in the collection of the British Museum. Part 1. Chondropterygii. London, British Museum (Natural History), $160 \mathrm{p}$.

Günther, A.C.L.G. 1870. Catalogue of the Fishes in the British Museum. The Trustees, $369 \mathrm{p}$

Herm, D. 1969. Marines Pliozän und Pleistozän in Nord-und MittelChile unterbesonderer Berücksichtigung der Entwicklung der Mollusken-Faunen. Zitteliana, 2:1-159.

Hernández, S.; González, M.T.; Villaroel, J.C. \& Acuña, E. 2010. Seasonal variation in fish bycatch associated with an artisanal flounder fishery on Coquimbo Bay, Chile. Revista de Biología Marina y Oceanografia, 45:695-703. doi:10.4067/s071819572010000400013

Hernández, S.; Haye, P. \& Shivji, M. 2008. Characterization of the pelagic shark fin trade in north central Chile by genetic identification and trader surveys. Journal of Fish Biology, 73:2293-2304. doi:10.1111/j.1095-8649.2008.02016.x

Hernández, S. \& Lamilla, J. 2004. Presencia del gran Tiburon blanco Carcharodon carcharias en las costas de Chile. In: CONGRESO DE CIENCIAS DEL MAR, 24, 2004. Resúmenes, La Serena.

Jordan, D.S. \& Evermann, B.W. 1896. The fishes of North and middle America: a descriptive catalogue of the species of fishlike vertebrates found in the waters of America, North of the Isthmus of Panama. Part I. Bulletin of the United States National Museum, 47:1-1240.

Jordan, D.S. \& Hannibal, H. 1923. Fossil sharks and rays of the Pacific Slope of North America. Bulletin of the Southern California Academy of Sciences, 22:27-63.

Kazar, E. 2002. Revised phylogeny of the Physeteridae (Mammalia: Cetacea) in light of Placoziphius Van Beneden, 1869 and Aulophyseter Kellogg, 1927. Bulletin de l'Institute Royal des Sciences Naturelles de Belgique, Sciences de la Terre, 72:151-170.

Kemp, N.R. 1991. Chondrichthyans in the Cretaceous and Tertiary of Australia. In: P. Vickers-Rich; J.M. Monaghan; R.E. Baird \& T.H. Rich (eds.) Vertebrate Palaeontology of Australasia, Pioneer Design Studio/Monash University Publications Committee, p. 498-531.

Kent, B.W. 1994. Fossil Shark of the Chesapeake Bay Region. Maryland, Egan Rees \& Boyer Inc., 146 p.

Keyes, I.W. 1982. The Cenozoic sawshark Pristiophorus lanceolatus (Davis) (Order Selachii) of New Zealand and Australia, with a review of the phylogeny and distribution of world fossil and extant Pristriophoridae. New Zealand Journal of Geology and Geophysics, 25:459-474. doi:10.1080/00288306.1982.10421510 
Le Roux, J.P.; Gómez, C.; Fennerand, J.H. \& Middleton, H. 2004. Sedimentological processes in a scarp-controlled rocky shoreline to upper continental slope environment, as revealed by unusual sedimentary features in the Neogene Coquimbo Formation, North-Central Chile. Sedimentary Geology, 165:6792. doi:10.1016/j.sedgeo.2003.11.006

Le Roux, J.P.; Olivares, D.M.; Nielsen, S.N; Smith, N.D.; Middleton, H.; Fenner, J. \& Ishman, S.E. 2006. Bay sedimentation as controlled by regional crustal behaviour, local tectonics and eustatic sea-level changes: Coquimbo formation (MiocenePliocene), Bay of Tongoy, central Chile. Sedimentary Geology, 184:133-153. doi:10.1016/j.sedgeo.2005.09.023

Lesueur, C.A. 1818. Description of several new species of North American fishes (part 1). Journal of the Academy of Natural Sciences of Philadelphia, 1:222-235.

Linnaeus, C. 1758. Systema naturae. $10^{\text {th }}$ ed. Stockholm, Larentii Salvii, $824 \mathrm{p}$.

Long, D.J. 1993. Late Miocene and early Pliocene fish assemblages from the North Central coast of Chile. Tertiary Research, 14:117-126.

Marquardt, C. 1999. Neotectónica de la franja costera y aportes a la geología regional entre Caldera y Caleta Pajonal $\left(27^{\circ}-27^{\circ} 45^{\text {, }}\right.$ S), III Región de Atacama, Chile. Departamento de Geología, Universidad de Chile, Tesis de grado, $297 \mathrm{p}$.

Marsili, S. 2007. Analisi sistematica, paleoecologica e paleobiogeografi ca della Selaciofauna plio-pleistocenica del Mediterraneo. Dipartimento di Scienze della Terra, Università di Pisa, Tesi di dottorato, $245 \mathrm{p}$.

Martínez-Pardo, R. 1979. Hallazgo de foraminíferos miocénicos cerca de Puerto Aldea, bahía de Tongoy, Provincia de Coquimbo, Chile. Revista Geológica de Chile, 8:65-78.

Morocco, R. \& Muizon, C. 1988. Los vertebrados del Neogeno de La Costa Sur del Perú: Ambiente sedimentario y condiciones de fosilización. Bulletin de l'Institut Frances d'Etudes Andines, 17:105-117.

Muizon, C. 1978. Arctocephalus (Hydrarctos) lomasiensis, subgen. nov. et nov. sp., un nouvel Otariidae du Mio-Pliocene de Sacaco. Bulletin de l'Institute Francais d'Etudes Andines, 7:169-189.

Muizon, C. 1988. Les vertebres fossiles de la formation Pisco (Peru). Troisieme partie: les Odontocetes (Cetacea, Mammalia) du Miocene. Editions Recherche sur les Civilisations, 78:1-244.

Muizon, C. \& DeVries, T.J. 1985. Geology and paleontology of late Cenozoic marine deposits in the Sacaco area (Peru). Geologische Rundschau, 74:547-563. doi:10.1007/bf01821211

Müller, J. \& Henle, F.G.J. 1837. Gattungen der Haifische und Rochen nach einer von ihm mit Hrn. Henle unternommenen gemeinschaftlichen Arbeit tiber die Naturgeschichte der Knorpelfische.Akademie der Wissenschaften zu Berlin, 2:111-118.

Müller, J. \& Henle, F.G.J. 1838. Ueber die Gattungen der Plagiostomen. Archiv für Naturgeschichte, 4:83-85.

Müller, J. \& Henle, F.G.J. 1838-1841. Systematische Beschreibung der Plagiostomen. Berlin, Veit, p 1-28, 1838d; p. 27-28 (reset), p. 29-102, 1839, p. 103-200.

Nel, A. et al. 1999. Un gisement sparnacien exceptionnel à plantes, arthropodes et vertébrés (Éocène basal, MP7): le Quesnoy (Oise, France). Comptes Rendus de l'Académie des Sciences - Series IIA - Earth and Planetary Science, 329:65-72. doi:10.1016/ s1251-8050(99)80229-8

Nishida, K. 1990. Phylogeny of the Suborder Myliobatoidei. Sapporo, Hokkaido University, p. 1-108 (Memoirs 37).

Ohmi, K. 1986. Three fossil marine mammals from the Neogene of Sakiyama Peninsula, Ishikawa Prefecture, Central Japan. Chikyu kagaku, 40:449-452.
Paskoff, R. 1970. Recherches geómorphologiques dans le Chili semi-aride. Bordaux, Biscaye, $420 \mathrm{p}$.

Pequeño, G. 1989. Peces de Chile. Lista sistemática revisada y comentada. Revista de Biología Marina, 24:1-132.

Pequeño, G. \& Sáez, S. 2003. The shark Carcharhinus galapagensis from Salas y Gómez Island, Chile (Chondrichthyes: Carcharhinidae). Revista de Biología Tropical, 51:795-796.

Phillipi, R.A. 1887. Los fósiles Terciarios i Cuartarios de Chile. Leipzig, Brockhaus, $256 \mathrm{p}$.

Pimiento, C. \& Clements, C.F. 2014. When did Carcharocles megalodon become extinct? A new analysis of the fossil record. PLOS ONE, 9: e111086. doi:10.1371/journal.pone.0117877

Pimiento, C.; Ehret, D.J.; MacFadden, B.J. \& Hubbell, G. 2010. Ancient nursery area for the extinct giant shark Megalodon from the Miocene Panama. PLOS ONE, 5: e10552. doi:10.1371/ journal.pone.0010552

Pimiento, C.; González-Barba, G.; Ehret, D.J.; Hendy, A.J.W.; MacFadden, B.J. \& Jaramillo, C. 2013b. Sharks and rays (Chondrichthyes, Elasmobranchii) from the late Miocene Gatun Formation of Panama. Journal of Paleontology, 87:755-774. doi:10.1666/12-117

Pimiento, C.; González-Barba, G.; Hendy, A.; Jaramillo, C.; MacFadden, B.; Montes, C.; Suárez, S., \& Shippritt, M. 2013a. Early Miocene Chondrichthyes from the Culebra Formation, Panama: a window into marine vertebrate faunas before closure the Central American Seaway. Journal of South American Earth Sciences, 42:159-170. doi:10.1016/j.jsames.2012.11.005

Portell, R.W.; Hubbel, G.; Donovan, S.K.; Green, J.L.; Harper, D.A.T. \& Pickerill, R. 2008. Miocene sharks in the Kendeace and Grand Bay formations of Carriacou, The Grenadines, Lesser Antilles. Caribbean Journal of Science, 44:279-286.

Purdy, R.W.; Schneider, V.P.; Applegate, S.P.; McLellan, J.H.; Meyer, R.L. \& Slaughter, B.H. 2001. The Neogene sharks, rays, and bony fishes from Lee Creek Mine, Aurora, North Carolina. Smithsonian Contributions to Paleobiology, 90:71-202.

Quilodrán, P. \& Marquardt, C. 2001. Catastro y condiciones de fosilización de cetáceos neogenos de la Formación Bahía Inglesa, 27-28S Tercera Región, norte de Chile. Ameghiniana, 38:15-16.

Radtke, U. 1989. Marine Terrassen und Korrallenriffe. Das Problem der quartären Meeresspiegelschwankungen erläutert an Fallstudien aud Chile, Argentinien und Barbados. Düsseldörfer Geographische Schriften, 27:1-246.

Rafinesque, C.S. 1810. Caratteri di alcuni nuovi generi e nouve specie di Animali e Piante della Sicilia con varie osservazioni sopra I medesimi. Palermo, Del Regno, 105 p.

Reinecke, T.; Louwye, S.; Havekost, U. \& Moths, H. 2011. The elasmobranch fauna of the late Burdigalian, Miocene, at WerderUesen, lower Saxony, Germany, and its relationships with early Miocene faunas in the North Atlantic, Central Paratethys and Mediterranean: Palaeontos, 20:1-170.

Risso, A. 1810. Ichthyologie de Nice, ou histoire naturelle des poissons du département des Alpes Maritimes. Paris, F. Schoell, 388 p.

Rivadeneira, M.M. \& Marquet, P.A. 2007. Selective extinction of late Neogene bivalves on the temperate Pacific coast of South America. Paleobiology, 33:455-468. doi:10.1666/06042.1

Rivadeneira, M.M. \& Varas, C. 2012. Linea base sector paleontológico del área marina y costera protegida de múltiples usos Isla Grande de Atacama. Proyecto 'Centro de Investigación y Conservación del Patrimonio Paleontológico del AMCP-MUIsla Grande de Atacama', 33 p.

Rojo, M. 1985. Un aporte al conocimiento del Terciario marino: Formación Bahía Inglesa. In: CONGRESO GEOLÓGICO CHILENO, 4, 1985. Resúmenes, p. 514-533. 
Rüppell, E. 1837. Newe Wirbelthiere zu der Fauna von Abyssinien gehörig. Fische des

Rothen Meeres. Frankfurt am Main, 1-148, p. 1-33. 1835:1-28, p. $1-7 ; 1836: 29-52$, p. $8-14 ; 1837: 53-80$, p. 15-21; 1838:81-148, p. 22-33.

Schindler, T.; Nungesser, K.; Mueller, A. \& Grimm, K.I. 2009. Die Alzey-Formation der klassichen Lokalitat Wlschberg bei Waldbockelheim (Rupelium, Oligozan, Mainzer Becken)Ergebnisse neuer Grabungen. Jahresberichte und Mitteilungen des Oberrheinischen Geologischen Vereines, 91:37-87. doi:10.1127/jmogv/91/2009/37

Snodgrass, R.E. \& Heller, E. 1905. Papers from the HopkinsStanford Galapagos Expedition, 1898-1899. XVII. Shore fishes of the Revillagigedo, Clipperton, Cocos and Galapagos Islands. Proceedings of the Washington Academy of Sciences, 6:333-427.

Suárez, M.E. \& Brito, J.L. 2000. Una nueva localidad con vertebrados fósiles del Terciario de Bahía Salado, Chile. In: JORNADAS ARGENTINAS DE PALEONTOLOGÍA DE VERTEBRADOS, 15, 2000. Resúmenes, San Luis, p. 57.

Suárez, M.E. \& Encinas, A. 2002. Vertebrados marinos del miembro inferior de la Formación Navidad (Mioceno temprano), Chile Central. In: CONGRESO LATINOAMERICANO DE PALEONTOLOGIA DE VERTEBRADOS, 5, 2002. Resúmenes, Santa Cruz de la Sierra, p. 51-52.

Suárez, M.E.; Encinas, A. \& Ward, D. 2006. An early Miocene elasmobranch fauna from the Navidad Formation, Central Chile, South America. Cainozoic Research, 4:3-18.

Suárez, M.E.; Lamilla, J. \& Marquardt, C. 2004. Peces Chimaeriformes (Chondrichthyes, Holocephali) del Neógeno de la Formación Bahía Inglesa, Región de Atacama, Chile. Revista Geológica de Chile, 31:105-117. doi:10.4067/s0716-02082004000100006

Suárez, M.E. \& Marquardt, C. 2003. Revisión preliminar de las faunas de peces elasmobranquios del Mesozoico y Cenozoico de Chile: su valor como indicadores cronoestratigráficos. In: CONGRESO GEOLÓGICO CHILENO, 10, 2003. Actas, Concepción, p. 9.

Taniuchi, T. 1990. The role of elasmobranchs in Japanese fisheries. In: H.L. Pratt; S. Gruber \& T. Taniuchi (eds.) Elasmobranchs as living resources: advances in the biology, ecology, systematics, and the status of the fisheries, NOAA, p. 415-426 (Technical Report 90).

Tsuchi, R. 2002. Neogene evolution of surface marine climate in Pacific and notes on related events. Revista Mexicana de Ciencias Geológicas, 19:260-270.
Underwood, C.J.; Michell, S.F. \& Veltkamp, K.J. 1999. Shark and Ray teeth from the Hauterivian (lower Cretaceous) of NorthEast England. Palaeontology, 42:287-302. doi:10.1111/14754983.00074

Valenzuela-Toro, A.M.; Gutstein, C.S.; Varas-Malca, R.M.; Suárez, M.E. \& Pyenson, N.D. 2013. Pinniped turnover in the South Pacific Ocean: new evidence from the Plio-Pleistocene of the Atacama Desert, Chile. Journal of Vertebrate Paleontology, 33:216-223. doi:10.1080/02724634.2012.710282

Villafaña, J.A. \& Rivadeneira, M.M. 2013. Cambios paleobiogeográficos de elasmobranquios del Neógeno en el Pacífico de Sudamérica. In: CONGRESO DE CIENCIAS DEL MAR, 33, 2013. Resúmenes, Antofagasta, p. 60.

Villafaña, J.A. \& Rivadeneira, M.M. 2014. The rise and fall of the diversity of marine vertebrates during the Neogene on the temperate Pacific coast of South America. Paleobiology, 40:659674. doi:10.1666/13069

Walsh, S.A. 2001. The Bahí Inglesa formation bonebed: genesis and palaeontology of a Neogene konzentrat lagerstätte from NorthCentral Chile. University of Portsmouth, Ph.D. thesis, 443 p.

Walsh, S. \& Hume, J. 2001. A new Neogene marine avian assemblage from North-Central Chile. Journal of Vertebrate Paleontology, 21:484-491. doi:10.1671/0272-4634(2001)021[0484:annma a] 2.0.co;2

Walsh, S. \& Naish, D. 2002. Fossil seals from late Neogene deposits in South America: a new pinniped (Carnivora, Mammalia) assemblage from Chile. Paleontology, 45:821-842. doi:10.1111/1475-4983.00262

Ward, D.J. \& Bonavia, C.G. 2001. Additions to, and a review of, the Miocene shark and ray fauna of Malta. The Central Mediterranean Naturalist, 3:131-146.

Welton, B.J. \& Zinsmeister, W.J. 1980. Eocene Neoselachians from the La Meseta Formation, Seymour Island, Antarctic Peninsula. Contributions in Science, Los Angeles County Museum, 329:1-10.

Whitmore, F. 1987. Cetacea from the Sahabi formation. In: N.T. Boaz; A. El-Arnauti; A.W. Gaziry; J. Heinzelin \& D.D. Boaz (eds.) Neogene Paleontology and Geology of Sahabi, Liss, p. 145-151.

Zachos, J.; Pagani, M.; Sloan, L.; Thomas, E. \& Billups, K. 2001. Trends, rhythms, and aberrations in global climate $65 \mathrm{Ma}$ to Present. Science, 292:686-693. doi:10.1126/science.1059412

Received in September, 2014; accepted in June, 2015. 